\title{
Archean Itabirites From Ovan, NE-Gabon: Petrography, Mineralogy And Elemental Mapping
}

\author{
Stévy Retonda-Kondja, \\ Simplice Marin Ndong-Ondo, \\ Ambroise Edou-Minko \\ University of Sciences and Technologies of Masuku, URESTE, Geology \\ Department, Franceville, Gabon \\ Tomohiko Sato, \\ Earth-Life Science Institute (ELSI), Tokoyo Institute of Technology, \\ Okayama, Meguro-ku, Japan \\ Benjamin Musavu-Moussavou, \\ Mathieu Moussavou \\ University of Sciences and Technologies of Masuku, URESTE, Geology \\ Department, Franceville, Gabon
}

Doi:10.19044/esj.2021.v17n25p380

Submitted: 26 May 2021

Accepted: 22 June 2021

Published: 31 July 2021
Copyright 2021 Author(s)

Under Creative Commons BY-NC-ND

4.0 OPEN ACCESS

Cite As:

Retonda-Kondja S., Ndong-Ondo S.M., Edou-Minko A., Sato T., Musavu-Moussavou B. \& Moussavou M. (2021). Archean Itabirites From Ovan, NE-Gabon: Petrography, Mineralogy And Elemental Mapping. European Scientific Journal, ESJ, 17(25), 380.

https://doi.org/10.19044/esj.2021.v17n25p380

\section{Abstract}

The Archean greenstone belt called Bélinga Group was highlighted in NE-Gabon around 1960. It consists of many petrographic types such as itabirites (BIFs), ultrabasites, and amphibolites. Recent geophysical studies revealed the presence of BIFs and associated rocks at Ovan, which were linked to the Bélinga Group according to similar magnetic and some petrographic characteristics. Unfortunately, data on itabirites in respect with petrography, mineralogy and geochemistry are rare. This note aims at contributing to petrography, mineralogy and elemental mapping of Ovan itabirites on the one hand, and giving strong proofs that they belong to the Bélinga Group on the other. 
Field investigations bring samples from six sites around Ovan. Selected itabirites samples have been studied in petrography, mineralogy (XRD) and elemental mapping (SEM). Two (2) itabirites lithofacies are recognized: the well-banded and the massive itabirites. Mineral assemblages show principally quartz, magnetite, hematite and goethite. SEM images show euhedral to sub-euhedral grains of quartz and Fe-oxides of two types: the biggest (Fe1), seen as primary minerals within Fe-rich bands and the smallest (Fe2), as secondary minerals disseminated in the siliceous levels. Elemental mapping clearly reveals alternating Fe- and Si-rich bands with Fe-rich bands predominance. Finally, the itabirites around Ovan are sedimentary rocks essentially formed by chemical precipitation and belonging to the Bélinga Group.

Keywords: Archean, Bélinga Group, Itabirite, Ovan, Gabon

\section{Introduction}

Itabirites or Banded Iron Formations (BIFs) are iron-rich chemical sedimentary rocks generally consisting of bands/lamina of silica (chert/quartz) in alternance with bands of iron oxy-hydroxides (magnetite, hematite, goethite). It sometimes contains iron carbonates (siderite and ankerite) or iron silicates (greenalite, grunerite...) (Bekker et al., 2014; Bekker et al., 2010; Li, 2014; Klein, 2005; Beukes \& Klein, 1990). Those BIFs are widespread in Precambrian greenstone belts and interest scientists on the one hand for their resources in iron (Li et al., 2014 ; Anderson et al., 2014 ; Duuring \& Hagemann, 2013; Roy \& Venkatesh, 2009; Ramanaidou, 2009; Spier et al., 2007; Hammond \& Moore, 2006; Webb et al., 2003), on the other hand for information about the beginnings of the Earth (Kramers et al., 2014; Liu et al., 2014; Bontognali et al., 2013; Thomazo et al., 2013; Ribeiro da Luz et al., 2012).

A huge ferriferous province situated in northwestern of the Archean Congo Craton includes S-Cameroun, NW-Congo and NE-Gabon. In NEGabon, there is the essential of the Bélinga Group which contains the Bélinga iron ore deposit, the biggest iron ore in Gabon (Rétonda Kondja et al., 2017; Combes et al., 1986; Sims, 1973). Occurrences of that Group are noted in other regions such as Mitzic, Ngama and Mébaga in Central-Gabon (Prian et al., 1998), Batouala, Boka-Boka and Makokou in NE-Gabon (Combes et al., 1986). The main petrographic types of the Bélinga Group are BIFs, metaultrabasites, amphibole-pyroxene rocks, amphibolites - amphibole gneisses, micro-conglomeratic quartzites, micaschist - chloritoschistes and amphibole/biotite gneisses (Abouma Simba et al., 2009a; Thiéblemont et al., 2009). According to their metamorphism degree, there are (a) granulite-BIFs facies consisting of quartz, magnetite, sillimanite and muscovite (Prian et al., 
1998), (b) amphibolite-BIFs facies with quartz, magnetite, and sometimes amphibole, garnet and orthopyroxene and (c) greenschist-BIFs facies containing quartz, hematite, goethite with little chlorite, illite and muscovite (Beaujour, 1971).

In Ovan area, recent geophysical prospections made by the General Direction of Mines and Geology revealed the presence of BIFs and associated rocks linked to the Bélinga Group (Abouma Simba et al., 2009a). However, petrographic or geochemical studies on Iron Formations in Ovan are rare. Therefore, it is important to investigate and bring more data for a better understanding of these rocks. The principal aim of the work is to give scientific proofs that itabirites from Ovan belong to the Bélinga Group. (i) Petrographic, (ii) mineralogical and (iii) elemental mapping characteristics of Ovan itabirites presented here link those rocks to the Bélinga Group.

\section{Regional geological setting}

The NE-Gabon region belongs to the North-Gabon Massif (Fig. 1a). It is a granites-greenstones terrane composed of an 3.0-2.7 Ga Archean basement including granites, gneisses and migmatites (TTG) that principally underwent granulite facies metamorphism, and a $\sim 2.8 \mathrm{Ga}$ greenstone belt called Bélinga Group essentially metamorphized under amphibolite facies, and locally granulite facies (Abouma Simba et al., 2009a; Thiéblemont et al., 2009; Chevallier et al., 2002).

In the Ovan-Makokou region, general trend of itbirites and ultrabasic to acidic rocks massifs, supported by geophysical data show a N-S to NW-SE of general direction. Four fault systems oriented NE-SW, NNW-SSE, E-W and NW-SE affect this Archean terrane. This area could be interpreted as a horstgraben system affected by combined shear faults (Rétonda Kondja et al., 2016). The study area is situated near Ovan, $\sim 140 \mathrm{~km}$ in SW of the Bélinga iron ore deposit (Fig. 1b).

\section{Material and methods}

During two field investigations in the forested study area with very little outcrops, six (6) indicated sites around Ovan have been explored (Fig. 1b). About hundred samples have been taken to get a maximum of lithofacies similar to those of the Bélinga Group.

For this work, only itabirites from sites 4 and 5 have been investigated in petrography, mineralogy and elemental mapping. Thin sections have been done at the School of Mines, Industry and Geology of Niamey (EMIG), Niger. First petrographic observations were performed in the Petrographic Laboratory at the University of Sciences and Technologies of Masuku (Gabon), using an Optika B-353POL polarizing microscope in order to determine textural relationships. Furthermore, a Hitachi S-3400N Scanning 
Electron Microscope (SEM) with a Brucker 5010 EDS system has been used in backscattered electron mode at the Earth Life Science Institute (ELSI) of Tokyo for deeper petrographic and elemental mapping analyses. Before the analysis under the SEM, polished and thin sections are coated with osmium (Os). For petrographic studies, the SEM-images were obtained in the following conditions: voltage: $15 \mathrm{kV}$; current: $80 \mu \mathrm{A}$; working distance: 10.9 mm; counting: $5 \mathrm{~s}$.

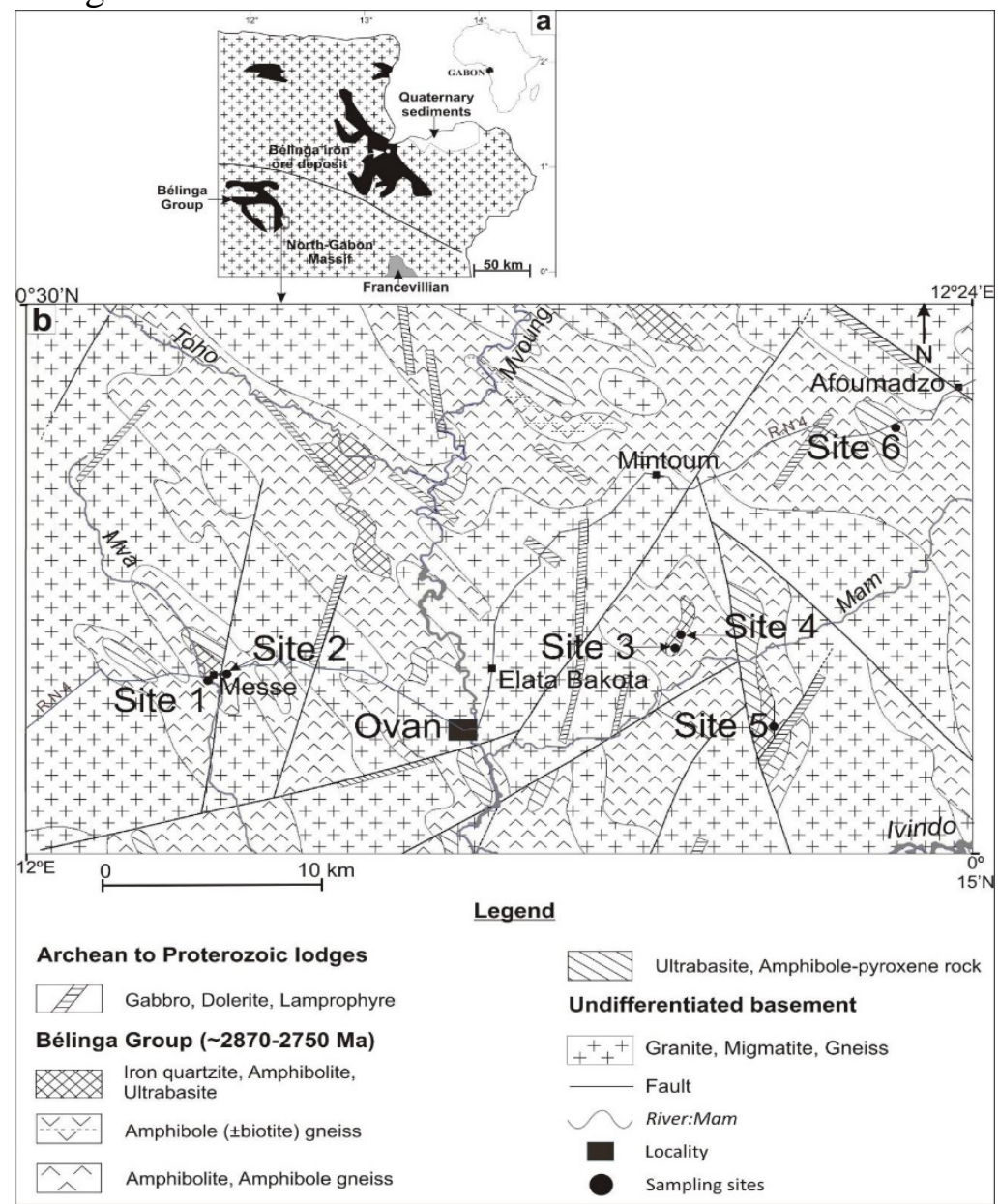

Figure 1. Location of the study area. (a) Simplified geological map of NE-Gabon (modified after Chevallier et al., 2002). (b) Geological map of the Ovan area and location of sampling sites (modified after Abouma Simba et al., 2009b). Itabirite samples come from Sites 4 and

The mapping of chemical elements was done with the same material as petrographic SEM analyses. The working conditions were the following: voltage of $15 \mathrm{kV}$; current: $80 \mu \mathrm{A}$; working distance: $10 \mathrm{~mm}$; counting: 1800 $\mathrm{s}$. The color scale shows the presence or a significant lack of an element when 
tint turns towards red or black respectively. SEM-images were treated with Quantax software.

Powder X-Ray Diffraction (XRD) was performed on total rock to provide bulk mineral assemblages. Rocks were powdered and particles <200 $\mu \mathrm{m}$ were used for XRD-analysis. The instrument used was a Siemens D5000 XRD at the Applied Chemistry of Solid Laboratory (LCSA) in Mohammed V University of Rabat, Morocco. Its parameters were as following: voltage: 40 $\mathrm{kV}$; CuKal radiation; scan: 10 to $60^{\circ}, 2 \theta$; current: $20 \mathrm{~mA}$; counting: $\sim 1 \mathrm{~h}$. XRD spectra were identified using data of Brindley and Brown (1980).

\section{Results}

\section{Petrographic features}

This part briefly presents the first petrographic results. For more details, see Rétonda Kondja et al. (2016). New SEM-results are presented. Itabirites observed in Ovan show two main lithofacies - well-banded and massive itabirites.

Well-banded itabirites are hard rocks consisting of centimetric to millimetric clear and dark colored levels which can be parallel (Fig. 2a, 2c), little undulated (Fig. 2d) or folded (Fig. 2f). Clear levels contain quartz with little iron oxy-hydroxides (mainly hematite) and dark-colored levels consist of magnetite, hematite and goethite. Clear levels are sometimes interrupted by iron oxides levels, highlighting the recrystallization process of primary magnetite to hematite in substitution for silica. Microscopic studies show granoblastic banded textures (Fig. 2b, 2e) with the same minerals, and locally hornblende.

SEM-images show two types of organizations (Fig. 3a). The first organization shows alternations of light grey colored bands with predominantly iron minerals and dark grey bands essentially composed of silica. A second organization shows iron minerals within silica bands. In the first organization, the dark grey silica bands exhibit euhedral to sub-euhedral aggregates of quartz with size between 100 and $300 \mu \mathrm{m}$. Iron mineral bands exhibit euhedral to sub-euhedral aggregates of iron oxides (mainly magnetite) of $200 \mu \mathrm{m}(\mathrm{Fe} 1)$ following banding direction (Fig. 3a, St4-2-002). In the second organization, hematite grains (Fe2) have sizes inferior to $100 \mu \mathrm{m}$ (Fig. 3a, St4-2-004). Elemental mapping in Si-Fe transition zones (Fig. 3b and 3c) with high resolution SEM-images does not show sharp limits. Silica-rich bands are often interrupted by intercalations of linking hematite grains to those of silica-rich bands and inversely on the one hand. On the other hand, we note a random distribution of iron oxides disseminated within silica bands keeping a preferred direction. 


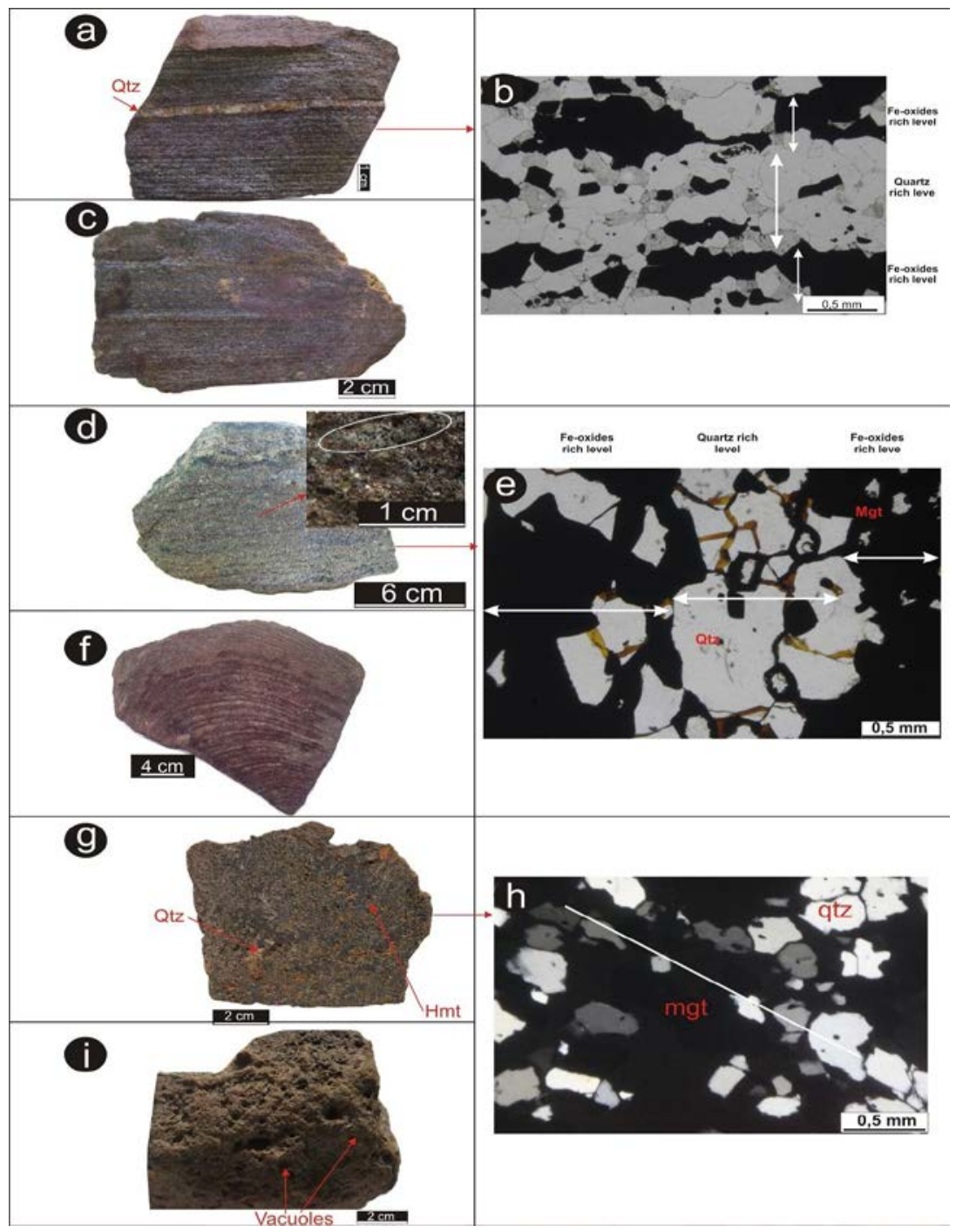

Figure 2. Hand specimens and photomicrographs (transmitted light) of itabirites from Ovan area. (a, c) Parallel banding. Quartz-rich bands are light and Fe-oxide-rich bands are dark. (b) Microbanding of the same itabirites. (d) Undulated banding; zoom on micro-pores. (e) Microscopic details with preserved banding. (f) Well-banded folded itabirites. (g) Polished section of a massive itabirites. (h) Photomicrograph of a massive itabirites showing slight mineral orientation. (i) Vacuoles on a massive itabirites. Mgt=magnetite; Hmt=hematite;

$\mathrm{Qtz}=$ quartz 


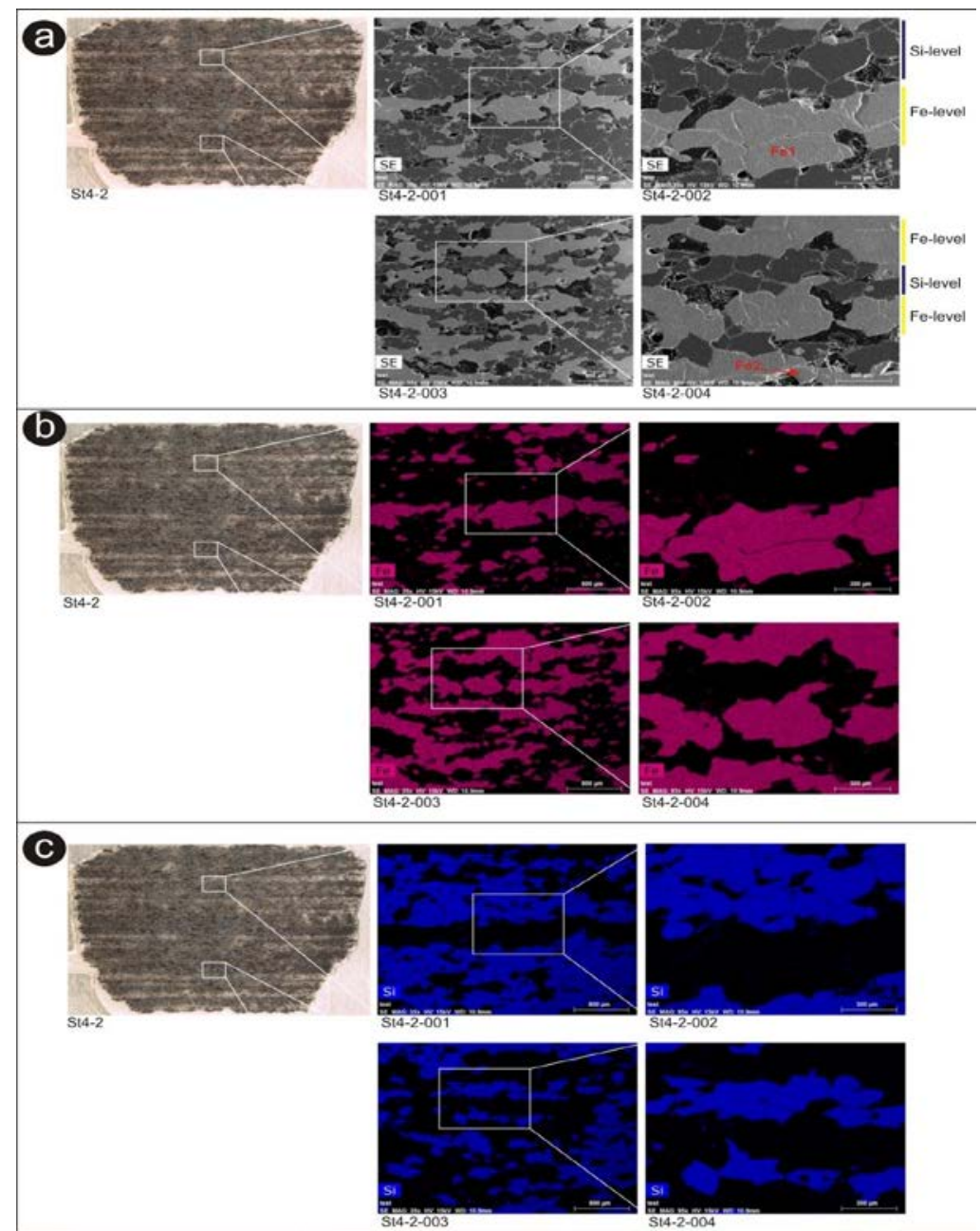

Figure 3. Photomicrographs (SEM) of a polished thin section for a well-banded itabirite. (a) Light grey bands are quartz-rich and dark grey bands are iron oxides-rich. (b, c) Elemental mapping showing microstructuration of iron-rich (purple) and silica-rich (blue) bands

Massive itabirites are grey-purple to reddish colored (Fig. 2g-i) with terrigenous spall and a density higher than the well-banded itabirites ones. They present millimetric to centimetric vacuoles on the faces which suffer direct weathering. They consist of medium to large quartz grains mixed with iron oxy-hydroxides, principally hematite and accessory magnetite and goethite (Fig. 2g). Microscopic studies reveal a granoblastic texture. The initial banding disappeared due to weathering (Fig. 2h). Nevertheless, a frustrated foliation is noted. New crystallized hematite is more abundant than other iron minerals. Its preponderance (more than 50\%) inside the rock suggests desilication process and iron enrichment in comparison with primary rock. Primary magnetite is replaced or martitized, goethite is locally noted. 


\section{X-Ray Diffraction (XRD)}

XRD results obtained on total sampled powder rock from well-banded and massive itabirites highlight the presence of quartz, magnetite, hematite, goethite and ferrihydrite (Fig. 4a and $4 \mathrm{~b}$ ). The quartz peaks are observed at 3.3 $\AA, 2.12 \AA$ and $1.81 \AA$, the highest intensity being at $3.3 \AA$. Magnetite is identified at $2.1 \AA$. Hematite has a peak at $2.68 \AA$ and ferrihydrite at $4.2 \AA$. Those of goethite are at $2.27 \AA$ and $1.69 \AA$. Magnetite-maghemite association corresponds to $2.51 \AA$, maghemite being the dimorph of hematite coming from magnetite oxidation.

Globally, itabirites analyzed have mineral associations consisting of magnetite, hematite and quartz probably as primary minerals, and goethite, maghemite and ferrihydrite as secondary minerals.

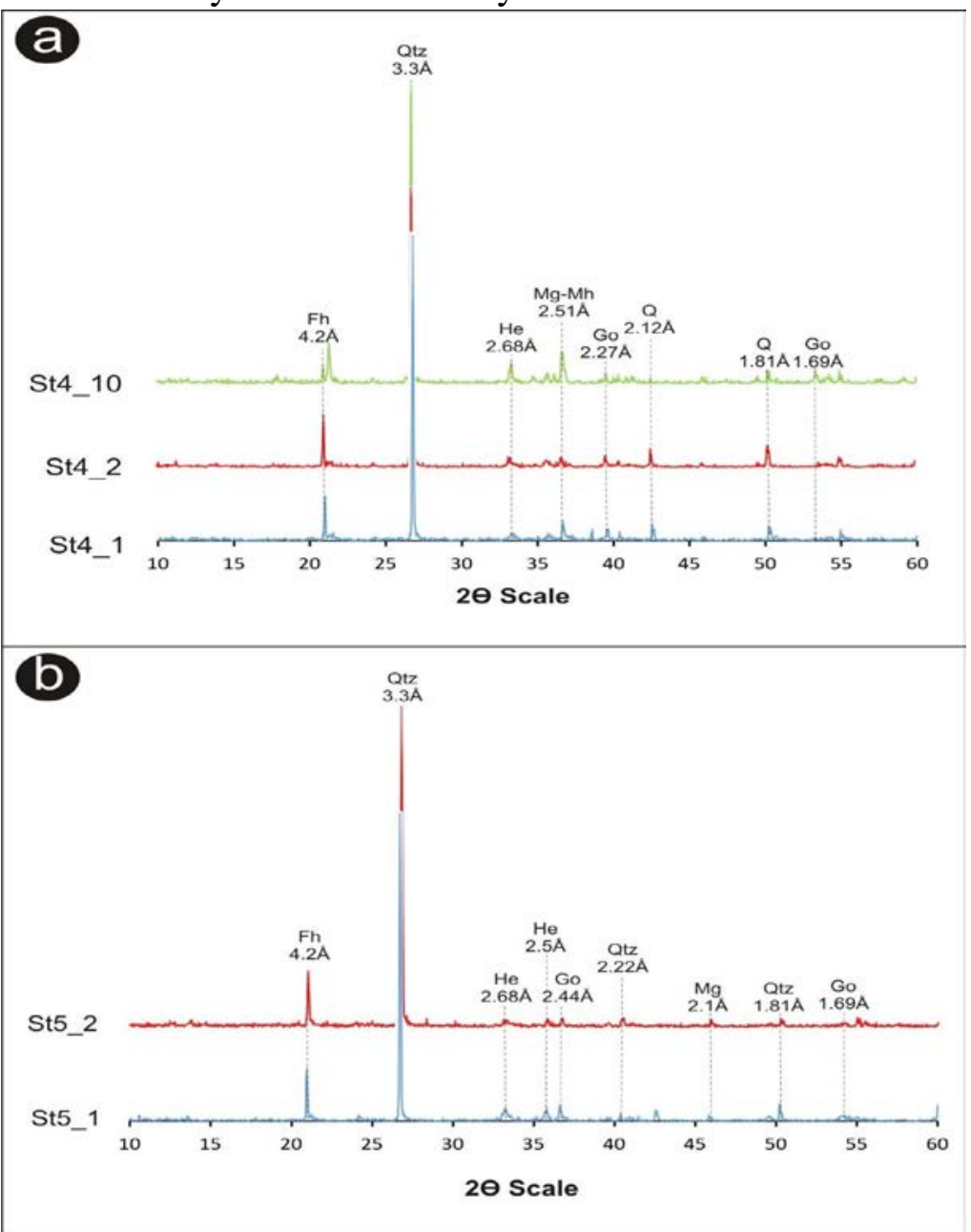

Figure 4. XRD patterns on total sampled powder rock of Ovan itabirites. (a) Well-banded itabirites from Site 4. (b) Massive itabirites from Site 5. Qtz=quartz, Mg=magnetite, $\mathrm{Mh}=$ maghemite, $\mathrm{He}=$ hematite, $\mathrm{Go}=$ goethite, $\mathrm{Fh}=$ ferrihydrite. 


\section{Elemental mapping}

Elemental mapping on well-banded itabirites (Fig. 5) shows that major constituents are Fe in yellow-orange tint estimated at $~ 55-60 \%$, Si in grey tint estimated at $\sim 30-35 \%$, whereas elements like Mn and Ca turn towards bluish tints. Chemical elements such as $\mathrm{Al}, \mathrm{Mg}, \mathrm{K}, \mathrm{S}$ and $\mathrm{P}$ are almost absent due to dark tint.

Among trace elements, Co is more abundant with a yellow-orange tint in comparison to $\mathrm{Cr}, \mathrm{Zn}, \mathrm{Ni}$, Mo or Re in bluish tints (Fig. 5). St4-1
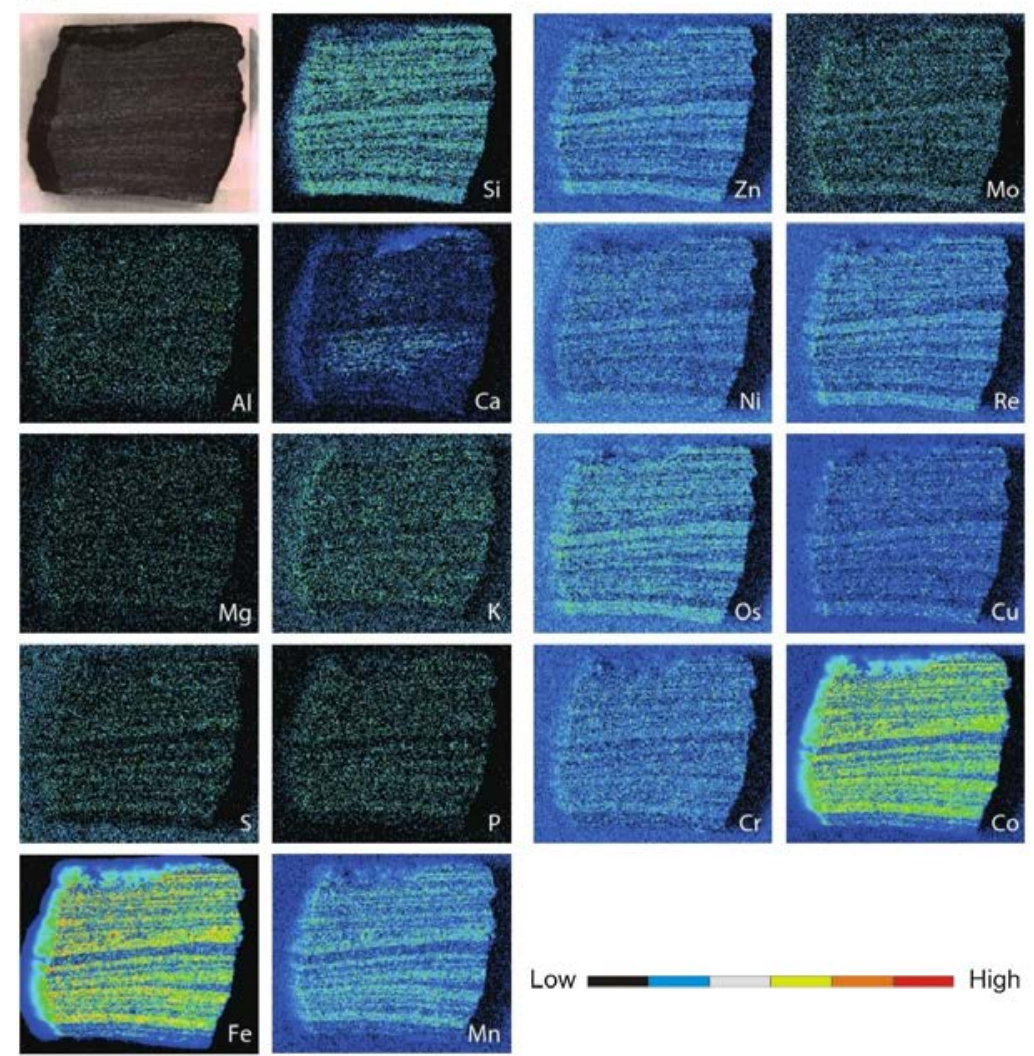

Low

Figure 5. Geochemical concentrations (SEM) of some elements of a well-banded itabirite (St4-1)

\section{Discussion}

Itabirites closely linked to iron ores in NE-Gabon, especially at Bélinga, have been known for a long time (Combes et al., 1986; Sims, 1973; Beaujour, 1971, 1964; Stahl \& Pohner, 1957). They have also been characterized in South of Gabon in Koumbi-Magnima (De Waele et al., 2017). This work in Ovan area constitutes a first study mixing petrography, mineralogy and elemental mapping of those rocks. 


\section{Ovan itabirites textural characteristics}

The study of siliceous itabirites around the world shows that they are chemical sedimentary rocks generally micro- to mesobanded consisting of iron oxy-hydroxides bands (magnetite, hematite, and goethite) in alternation with chert/quartz bands (Farquhar et al., 2010; Bekker et al., 2010; Trendall \& Bockley, 1970). Such textural characteristics are also reported for Gabon in regions like Bélinga, Batouala or even Boka-Boka (Thiéblemont et al., 2009; Combes et al., 1986). In Ovan, except massive itabirites which could be considered as iron ores coming from weathering of well-banded itabirites, the others are microbanded like itabirites from Bélinga and Batouala with microscopic banded granoblastic textures.

\section{Mineral assemblages}

De Waele et al. (2017), Thiéblemont et al. (2009) and Prian et al. (1998) notice that moderate to strongly weathered itabirites contain quartz, magnetite, hematite and often goethite. In Ovan, both massive and well-banded itabirite samples have identical mineral assemblages (XRD) consisting of quartz, hematite, magnetite, goethite and ferrihydrite. Mineral assemblages recognized in the petrographic study from Ovan itabirites are similar to those of XRD, except for ferrihydrite. Such mineral assemblages suggest a strong proximity of Ovan itabirites with those of Bélinga, Mitzic or KoumbiMagnima.

According to petrographic observations, the most preserved minerals are quartz in clear bands, magnetite and hematite in iron minerals rich-bands on the one hand, and on the other hand hematite in the siliceous levels of Fe-Si transition zones.

\section{Hematite formation}

SEM petrographic studies reveal two types of iron minerals (Fig. 3a), those of great size within iron minerals rich-bands (Fe1) and those of small size disseminated within siliceous levels (Fe2). Ahn \& Buseck (1990) suggest that hematite Fe1-crystals could be primary minerals which take form by dehydration of ferrihydrite during early diagenesis. Smaller Fe2-crystals disseminated within siliceous levels could also originate from dehydration of iron oxy-hydroxide precursors, but differ from Fe1-crystals because they undergo growth process facilitated by surrounding silica which grouped not only hematite particles but also released water within its structure during the transformation of amorphous silica (Meng et al., 2009; Frondel, 1982). Structural water inside silica rich-bands would have been preserved during geological times. Its mobilization during diagenesis or metamorphism would facilitate the growth of Fe2-hematite crystals (Morse \& Casey, 1988). The latter would be relics of a later phase. 
Moreover, the limits between Fe and Si rich-bands are irregular. This suggests recrystallization processes of primary magnetite to hematite by silica removing (Duuring \& Hagemann, 2013; Lascelles, 2012). This substitution of silica by iron minerals, marked near Fe-Si limits by discontinuities, even by interpenetrations of oxy-hydroxides within silica bands suggests that a part of hematite, and probably magnetite, was formed later in the silica part. Great size Fe1-hematite crystals could still be interpreted as primary precipitates, i.e. inherited ferric iron of primary minerals precipitated from seawater, small size Fe2-hematite crystals would not necessarily be of primary minerals themselves, but formed later during diagenesis or even the beginning of metamorphism because they are certainly linked to other coexisting iron minerals such as goethite (Morris, 2012, 1993; Rasmussen et al., 2013, 2014).

\section{Implications for the depositional process}

To understand the itabirites depositional processes, it is important to discern their original mineral compositions and the sources of mineralizing fluids. Ferric oxy-hydroxides such as ferrihydrite previously suggested that they could be primary minerals precipitated from the oceanic water column (Konhauser et al., 2007, 2002; Ahn \& Buseck, 1990). It is also suggested that disseminated Fe2-crystals within siliceous levels were also primary precipitates but formed later. In this work, Fe1- and Fe2-hematite crystals indicate that at least a part of hematite within the Ovan itabirites is primary and another part the latest, with ferrihydrite as precursor (Bekker et al., 2014; Klein, 2005).

Moreover, alternations of Si- and Fe-rich bands in itabirites reflect bottom conditions in which seawater has been saturated in silica and that iron would probably be of volcanogenic-hydrothermal origin (Bekker et al., 2014). Iron minerals rich-bands would form when Fe (II) supply or oxidation rate is relatively favorable to silica precipitation because of seasonal or temperature fluctuations, and inversely silica rich-bands would form when Fe (II) oxidation rate is unfavorable (Posth et al., 2008; Morris, 1993; Holland, 1973).

In addition, Tingguang et Hongrui (2014) suggest that itabirites with silica + iron concentrations of $\sim 92 \%$ of the whole rock were essentially formed by chemical precipitation. Bolhar et al. (2004) also indicate that low values of elements such as $\mathrm{Al}, \mathrm{Ti}$, Th, $\mathrm{Zr}, \mathrm{Cr}$ or $\mathrm{Ni}$ suggest that clastic components (crust) did not play a significant role during the deposition of itabirites. In Ovan, the estimated silica + iron concentrations of $~ 90-92 \%$ and low $\mathrm{Al}, \mathrm{Cr}$ and $\mathrm{Ni}$ contents of the rocks suggest that they were essentially formed by chemical precipitation. 


\section{Conclusion}

Based on petrographic, mineralogical and elemental mapping observations, the comparison of Ovan itabirites with those of Bélinga show two principal identified lithofacies: well-banded (parallel and folded) and massive itabirites. Petrographic characteristics of well-banded itabirites marked by alterations of clear bands consisting of quartz and some hematite grains, and dark-colored bands consisting of iron oxy-hydroxides are similar to those described at Bélinga, Batouala and other regions in the world.

Mineral assemblages deduced by XRD reveal the presence of quartz, magnetite, maghemite, hematite, goethite and ferrihydrite, and remain similar to those of Bélinga. SEM-observations show two types of microcrystals, euhedral to sub-euhedral quartz whose height varies between 100 and $200 \mu \mathrm{m}$, whereas aggregates of euhedral to sub-euhedral hematite microcrystals of $\sim 200 \mu \mathrm{m}$ (Fe1) and hematite microcrystals are under $100 \mu \mathrm{m}$ high (Fe2) disseminated within siliceous levels. Quartz, magnetite, Fe1- and Fe2hematite would have been inherited from primary iron precipitates and underwent growth processes during early diagenesis or even the first stage of metamorphism. Goethite would have been formed during the weathering stage.

The elemental mapping of chemicals from Ovan itabirites highlights the preponderance of Fe and Si as major constituents, minor Mn, Zn, Ca, Ni, Re, $\mathrm{Os}, \mathrm{Cu}$ and the quasi absence of $\mathrm{Al}, \mathrm{Mo}, \mathrm{Mg}, \mathrm{K}, \mathrm{S}$ and $\mathrm{P}$. This suggests an essentially chemical precipitation process.

\section{Acknowledgements}

We thank the Geology Department of the Faculty of Sciences from the University of Sciences and Technologies of Masuku (USTM, Gabon) for their assistance and the Earth Life Science Institute (ELSI) of Tokyo (Japan) for elemental mapping.

\section{References:}

1. Abouma Simba, S., Nagel, J.L., Ebang Obiang, M., \& Tegyey, M. (2009a). Notice explicative de la carte géologique à 1/200 000, feuille Makokou. Editions DGMG-Ministère des Mines, du Pétrole et des Hydrocarbures, Libreville, 45p.

2. Abouma Simba, S., Nagel, J.L., \& Ebang Obiang, M. (2009b). Carte géologique de la République du Gabon à 1/200 000, feuille Makokou. Editions DGMG-Ministère des Mines, du Pétrole, des Hydrocarbures, Libreville.

3. Anderson, K.F.E., Wall, F., Rollinson, G.K., \& Moon, C.J. (2014). Quantitative mineralogical and chemical assessment of the Nkout iron ore deposit, Southern Cameroon. Ore Geology Review, 62, 25-39. 
4. Ahn, J.H., \& Buseck, P.R. (1990). Hematite nanospheres of possible colloidal origin from a Precambrian banded iron formation. Science, 250, 111-113.

5. Beaujour, A., (1964). Mission voie ferrée 1965. Rapport de fin de campagne : Reconnaissance géologique et minière sur le tracé d'avantprojet de Voie Ferrée ; tronçon Makokou-Bélinga. DGGRM R-0471.

6. Beaujour, A., (1971). Notice explicative Makokou-Ouest et carte géologique de reconnaissance au 1/500 000. Ministère des Mines, des Ressources Hydrauliques et de l'Energie, Gabon. Paris, 49p.

7. Bekker, A., Slack, J.F., Planavsky, N., Krapež, B., Hofmann, A., Konhauser, K.O., \& Rouxel, O.J. (2010). Iron formation: The sedimentary product of a complex interplay among mantle, tectonic, oceanic, and biospheric processes. Economic Geology, 105, 467-508.

8. Bekker, A., Planavsky, N.J., Krapež, B., Rasmussen, B., Hofmann, A., Slack, J.F., Rouxel, O.J., \& Konhauser, K.O. (2014). Iron formations: Their origins and implications for ancient seawater chemistry, In Holland, H.D., and Turekian, K.K. (Eds)., Treatise on Geochemistry (2nd Ed.). Oxford, UK, Elsevier, 561-628.

9. Beukes, N.J., \& Klein, C. (1990). Geochemistry and sedimentology of a facies transition-from microbanded to granular iron-formation-in the early Proterozoic Transvaal Supergroup, South Africa. Precambrian Research, 47, 99-139.

10. Bontognali, T.R.R., Fischer, W.W., \& Föllmi, K.B. (2013). Siliciclastic associated banded iron formation from the 3.2 GaMoodiesGroup,Barberton Greenstone Belt, South Africa. Precambrian Research, 226, 116-124.

11. Brindley, G.W., \& Brown, G., (1980). Crustal structures of clay minerals and their X-ray identification. Mineralogical Society, London, 459p.

12. Chevallier, L., Makanga, J.F., \& Thomas, R.J. (2002). Notice explicative de la Carte géologique de la République gabonaise à 1/1 000 000. Editions DGMG-Ministère des Mines de l'Energie, du Pétrole et des Ressources Hydrauliques, 195p.

13. Combes, A., Derkmann, K., Donzeau, M., Moumpossa, S., Nziba, N., \& Vadala, P. (1986). Fer Haut-Ivindo, Rapport géologique. Rapport BRGM-86-GAB-094a.

14. Duuring, P., \& Hagemann, S. (2013). Genesis of superimposed hypogene and supergene $\mathrm{Fe}$ ore bodies in BIF at the Madoonga deposit, Yilgarn Craton, Western Australia. Mineralium Deposita, 48, 371-395. 
15. Farquhar, J., Zerkle, A.L., \& Bekker, A. (2010). Geological constraints on the origin of oxygenic photosynthesis. Photosynthesis Research, 107, 11-36.

16. Frondel, C. (1982). Structural hydroxyl in chalcedony (type B quartz). American Mineralogist, 67, 1248-1257.

17. Hammond, N.Q., \& Moore, J.M. (2006). Archaean lode gold mineralization in banded iron formation at the Kalahari Goldridge deposit, Kraaipan Greenstone Belt, South Africa. Mineralium Deposita, 41, 483-503.

18. Holland, H.D. (1973). The oceans: A possible source of iron in ironformations. Economic Geology, 68, 1169-1172.

19. Klein, C. (2005). Some Precambrian banded iron-formations (BIFs) from around the world: Their age, geologic setting, mineralogy, metamorphism, geochemistry, and origin. American Mineralogist, 90, 1473-1499.

20. Konhauser, K.O., Hamade, T., Raiswell, R., Morris, R.C., Ferris, F.G., Southam, G., \& Canfield, D.E. (2002). Could bacteria have formed the Precambrian banded iron formations? Geology, 30, 1079-1082.

21. Konhauser, K.O., Amskold, L., Lalonde, S.V., Posth, N.R., Kappler, A., \& Anbar, A. (2007). Decoupling photochemical Fe (II) oxidation from shallow-water BIF deposition. Earth and Planetary Science Letters, 258, 87-100.

22. Kramers, J.D., Henzen, M., \& Steidle, L. (2014). Greenstone belts at the northenmost edge of the Kaaapvaal Craton: Timing of tectonic events and a possible crustal fluid source. Precambrian Research, 253, 96-113.

23. Lascelles, D.F. (2012). Banded iron formation to high-grade iron ore: a critical review of supergene enrichment models. Australian Journal of Earth Sciences, 59, 1105-1125.

24. Li, Y.-L. (2014). Micro- and nanobands in late Archean and Palaeoproterozoic banded-iron formations as possible mineral records of annual and diurnal depositions. Earth and Planetary Science Letters, 391, 160-170.

25. Li, H., Zhang, Z., Li, L., Zhang, Z., Chen, J., \& Yao, T. (2014). Types and general characteristics of the BIF-related iron deposits in China. Ore Geology Review, 57, 264-287.

26. Liu, L., Zhang, L., \& Dai, Y. (2014). Formation age and genesis of the banded iron formations from the Guyang Greenstone Belt, Western North China Craton. Ore Geology Review, 63, 388-404.

27. Meng, D., Wu, X., Fan, F., Meng, X., Zheng, J., \& Mason, R. (2009). Submicron-sized fluid inclusions and distribution of hydrous components in jadeite, quartz and symplectite-forming minerals from 
UHP jadeite-quartzite in the Dabie Mountains, China: TEM and FTIR investigation. Applied Geochemistry, 24, 517-526.

28. Morris, R.C. (1993). Genetic modeling for banded iron formation of the Hamersley Group, Pilbara craton, Western Australia. Precambrian Research, 60, 243-286.

29. Morris, R.C. (2012). Microplaty hematite-Its varied nature and genesis. Australian Journal of Earth Sciences, 59, 411-434.

30. Morse, J.W., \& Casey, W.H. (1988). Ostwald processes and mineral paragenesis in sediments. American Journal of Science, 288, 537-560.

31. Prian, J.P., Ebang, M., Siméon, Y., Johan, V., Tourlière, B., \& Angel, J.M. (1998). Synthèse géologique et géochimie, potentialités minières du degré carré de Mitzic (Gabon central) avec carte géologique à 1/200 000. Editions DGMG-Ministère des Mines et des Hydrocarbures, 185p.

32. Posth, N.R., Hegler, F., Konhauser, K.O., \& Kappler, A. (2008). Alternating $\mathrm{Si}$ and Fe deposition caused by temperature fluctuations in Precambrian oceans. Nature Geoscience, 1, 703-708.

33. Ramanaidou, E.R. (2009). Genesis of lateritic iron ore from banded iron-formation in the Capanema mine (Minas Gerais, Brazil). Australian Journal of Earth Sciences, 56, 605-620.

34. Rasmussen, B., Meier, D., Krapež, B., \& Muhling, J.R. (2013). Iron silicate microgranules as precursor sediments to 2.5-billion-year-old banded iron formations. Geology, 41, 435-438.

35. Rasmussen, B., Krapež, B., \& Meier, D.B. (2014). Replacement origin for hematite in $2.5 \mathrm{Ga}$ banded iron formation: Evidence for post depositional oxidation of iron-bearing minerals. Geological Society of America Bulletin, 126, 438-446.

36. Rétonda Kondja, S., Ndong Ondo, S.M., Musavu Moussavou, B., Moussavou, M., Edou Minko, A., 2016. Pétrographie des Formations de fer rubanées et roches associées archéennes d’Ovan (NE-Gabon) : un exemple de roches du groupe de Bélinga. Revue du CAMES, Sciences de la vie, de la terre et agronomie, 04 (1), 75-82.

37. Rétonda Kondja, S., Ndong Ondo, S.M., Edou Minko, A., MayagaMikolo, F., 2017. The Bélinga Iron Ore Deposit ( 2.8 Ga), NE-Gabon: Reactualization and New Interpretations on Crests. European Scientific Journal, 13 (24), 307-321.

38. Ribeiro da Luz, B., \& Crowley, J.K. ( 2012). Morphological and chemical evidence of stromatolitic deposits in the 2.75Ga Carajás banded iron formation, Brazil. Earth and Planetary Science Letters, 355-356, 60-72.

39. Roy, S., \& Venkatesh, A.S. (2009). Mineralogy and geochemistry of banded iron formation and iron ores from eastern India with 
implications on their genesis. Journal of Earth System Science, 118, 619-641.

40. Sims, S.J. (1973). The Bélinga iron ore deposit (Gabon) In: Genesis of Precambrian iron and manganese deposits. Proceedings of the Kiev Symposium, Unesco, 323-334.

41. Spier, C.A., de Oliveira, S.M.B., Rosière, C.A., \& Ardisson, J.D. (2007). Mineralogy and trace-element geochemistry of the high grade iron ores of the Águas Claras Mine and comparison with the Capão Xavier and Tamanduá Iron ore deposits, Quadrilátero Ferrífero, Brazil. Mineralium Deposita, 43, 229-254.

42. Stahl, W., \& Pohner, A. (1957). Gisements des minerais de fer de Mecambo au Gabon - Afrique Equatoriale Française. Rapport BRGMF-02-224, 70p.

43. Thiéblemont, D., Castaing, C., Billa, M., Bouton, P., \& Preat, A. (2009). Notice explicative de la Carte géologique et des ressources minérales de la République Gabonaise à 1/1000 000. Edition DGMG - Ministère des Mines, du Pétrole, des Hydrocarbures, Libreville, 384p.

44. Thomazo, C., Nisbet, E., Grassineau, N., Peters, M., \& Strauss, H. (2013). Multiple sulfur and carbon isotope composition of sediments from the Belingwe Greenstone Belt (Zimbabwe): a biogenic methane regulation on mass independent fractionation of sulfur during the Neoarchean? Geochimica et Cosmochimica Acta, doi: http://dx.doi.org/10.1016/j.gca.2013.06.036.

45. Trendall, A.F., \& Blockley, J.G. (1970). The iron formations of the Precambrian Hamersley Group, Western Australia. Geological Survey of Western Australia Bulletin, 119, 366 p.

46. Webb, A.D., Dickens, G.R., \& Oliver, N.H.S. (2003). From banded iron-formation to iron ore: geochemical and mineralogical constraints from across the Hamersley Province, Western Australia. Chemical Geology, 197, 215-251. 